\title{
Bayesian approach increases accuracy when selecting cowpea genotypes with high adaptability and phenotypic stability
}

\author{
L.M.A. Barroso ${ }^{1 *}$, P.E. Teodoro ${ }^{2 *}$, M. Nascimento ${ }^{1}$, F.E. Torres ${ }^{2}$, A. dos Santos ${ }^{3}$, \\ A.M. Corrêa ${ }^{2}$, E. Sagrilo4 ${ }^{4}$, C.C.G. Corrêa ${ }^{2}$, F.A. Silva² and G. Ceccon ${ }^{5}$ \\ 1Departamento de Estatística, Universidade Federal de Viçosa, Viçosa, MG, Brasil \\ ${ }^{2}$ Departamento de Fitotecnia, Universidade Estadual de Mato Grosso do Sul, \\ Aquidauana, MS, Brasil \\ ${ }^{3}$ Departamento de Melhoramento Genético, \\ Universidade Estadual do Norte Fluminense Darcy Ribeiro, Campos dos Goytacazes, \\ RJ, Brasil \\ ${ }^{4}$ Embrapa Meio-Norte, Teresina, PI, Brasil \\ ${ }^{5}$ Embrapa Agropecuária-Oeste, Dourados, MS, Brasil \\ ${ }^{*}$ These authors contributed equally to this study. \\ Corresponding author: P.E. Teodoro \\ E-mail: eduteodoro@hotmail.com \\ Genet. Mol. Res. 15 (1): gmr.15017625 \\ Received September 11, 2015 \\ Accepted October 30, 2015 \\ Published March 11, 2016 \\ DOI http://dx.doi.org/10.4238/gmr.15017625
}

\begin{abstract}
This study aimed to verify that a Bayesian approach could be used for the selection of upright cowpea genotypes with high adaptability and phenotypic stability, and the study also evaluated the efficiency of using informative and minimally informative a priori distributions. Six trials were conducted in randomized blocks, and the grain yield of 17 upright cowpea genotypes was assessed. To represent the minimally informative a priori distributions, a probability distribution with high variance was used, and a meta-analysis concept was adopted to represent the informative a priori distributions. Bayes factors were used to conduct comparisons between the a priori distributions. The Bayesian approach was effective for selection
\end{abstract}


of upright cowpea genotypes with high adaptability and phenotypic stability using the Eberhart and Russell method. Bayes factors indicated that the use of informative a priori distributions provided more accurate results than minimally informative a priori distributions.

Key words: Vigna unguiculata L.; Bayes factor; Informative prior; Genotype x environment interaction

\section{INTRODUCTION}

Owing to the growing diversity of the cowpea [Vigna unguiculata (L.) Walp.], which is currently cultivated in three regions of Brazil, it is very important to investigate the magnitude of genotype $x$ environment interactions $(G \times E$ ) when choosing the best selection strategy and cultivar recommendations (Santos et al., 2014a,b). Therefore, some studies have been conducted in order to select cowpea genotypes with upright and prostrate sizes that are superior in adaptability and yield stability (Torres et al., 2015a). Several methodologies are used, including the Eberhart and Russell (1966) (based on linear regression) as well as Yates and Cochran (1938) (traditional) and Wricke (1965), which are both based on ANOVA (Freire Filho et al., 2002; Rocha et al., 2007; Barros et al., 2013; Santos et al., 2015).

Despite the large number of methodologies for the detailed study of $G \times E$, all make use of a priori information when estimating the parameters. The inclusion of a priori information can be performed using Bayesian inference. This approach uses three basic concepts: i) initial information (a priori probability), which is generally assumed to be a joint probability law on the parameters before obtaining the particular sample $\mathrm{y}_{1}, \ldots, \mathrm{y}_{\mathrm{n}}$ from random variables; ii) the probabilistic model of the random response variable $y$, which is used to obtain the sample likelihood, and iii) Bayes' theorem (Cotes et al., 2006). Thus, in a Bayesian context, the parameters are interpreted as random variables with a probability law (a priori distribution) that reflect the original information (or the lack of information) associated with them, regardless of what the data may show (Molina et al., 2011). In addition, the homogeneity of variance and the appropriateness of residues to a normal distribution are assumptions for many methodologies, but these are not required with the Bayesian approach (Cotes et al., 2006).

Despite being a robust statistical procedure with several possible applications, the use of Bayesian inference in genetic breeding is still limited. Mora et al. (2009) used the Bayesian approach to predict the heritability values of forest species, and concluded that this method made it possible to obtain low standard deviation values associated with heritability, which makes it an important tool for genetic breeding. Silva et al. (2013) used the Bayesian approach to select sugarcane families (Saccharum officinarum L.), and found that the informative a priori not only influenced the genetic effects, but it also influenced variance and heritability. Nascimento et al. (2011) formulated a Bayesian approach using the Eberhart and Russell (1966) method, and concluded that the selection of genotypes in different environments was most accurate when a priori information was used.

Thus, in order to generate relevant information regarding the genetic breeding of cowpeas, this study aimed to verify if the Bayesian approach could be employed for the selection of upright cowpea genotypes with high adaptability and phenotypic stability. Moreover, it also aimed to evaluate the efficiency of using informative and minimally informative a priori distributions. 


\section{MATERIAL AND METHODS}

Six trials using cowpea genotypes were conducted during the 2005 and 2006 agricultural years in the municipalities of Chapadão do Sul and Dourados, and the soil and climate features of the region are shown in Table 1. The experimental design included a randomized block design with 17 treatments and four replications. The experimental unit consisted of four $5.0 \mathrm{~m}$ rows with $0.5 \mathrm{~m}$ between each row, and the plants in each row were spaced $0.25 \mathrm{~m}$ apart. For each experimental unit, grain yield (YIE) was evaluated in two central rows, and it was corrected to $13 \%$ moisture and extrapolated to $\mathrm{kg} / \mathrm{ha}$.

Table 1. Number of trials (NT), agricultural year, site, latitude, longitude, altitude, Köppen's classification, and sowing date of cowpea [Vigna unguiculata (L.) Walp.] genotypes that were evaluated in the State of Mato Grosso do Sul.

\begin{tabular}{l|l|l|c|c|c|r|r}
\hline NT & Year & Site & Latitude & Longitude & Altitude $(\mathrm{m})$ & Köppen's classification & Sowing date \\
\hline 1 & 2005 & Aquidauana & $22^{\circ} 01^{\prime} \mathrm{S}$ & $54^{\circ} 05^{\prime} \mathrm{W}$ & 430 & Aw & March 21,2005 \\
\hline 2 & 2005 & Chapadão do Sul & $18^{\circ} 05^{\prime} \mathrm{S}$ & $52^{\circ} 04^{\prime} \mathrm{W}$ & 790 & Aw & March 14,2005 \\
\hline 3 & 2005 & Dourados & $20^{\circ} 03^{\prime} \mathrm{S}$ & $55^{\circ} 05^{\prime} \mathrm{W}$ & 147 & Cwa & April 7, 2005 \\
\hline 4 & 2006 & Aquidauana & $22^{\circ} 01^{\prime} \mathrm{S}$ & $54^{\circ} 05^{\prime} \mathrm{W}$ & 430 & Aw & March 2,2006 \\
\hline 5 & 2006 & Dourados & $20^{\circ} 03^{\prime} \mathrm{S}$ & $55^{\circ} 05^{\prime} \mathrm{W}$ & 147 & Cwa & February 27,2006 \\
\hline 6 & 2006 & Primavera & $15^{\circ} 33^{\prime} \mathrm{S}$ & $54^{\circ} 17^{\prime} \mathrm{W}$ & 636 & Aw & March 15,2006 \\
\hline
\end{tabular}

Treatments consisted of 14 lines (MNC99-537F-1, MNC99-537F-4, MNC99-541-F5, MNC99-541-F8, IT93K-93-10, MNC99-519D-1-1-5, MNC00-544D-10-1-2-2, MNC00-544D-14-1-22, MNC00-553D-8-1-2-2, MNC00-553D-8-1-2-3, MNC00-561G-6, EV X 63-10E, EV X 91-2E-2, and MNC99-557F-2) and three cowpea cultivars (BRS Guariba, Patativa, and Vita-7), which were obtained from Embrapa Meio-Norte cowpea genetic breeding program.

Data were subjected to individual ANOVA, and fixed and other treatment effects were considered random. The results indicated that the relationship between the highest and lowest mean square of the individual ANOVA of the residues did not exceed the 7:1 ratio, which allowed the implementation of joint analysis of trials (Banzatto and Kronka, 2006). The data were subsequently subjected to adaptability and stability analyses using the Eberhart and Russell (1966) method.

The adopted linear regression model of Eberhart and Russell (1966) was:

$$
\mathrm{Y}_{\mathrm{ij}}=\beta_{0 \mathrm{i}}+\beta_{\mathrm{i}} \mathrm{I}_{\mathrm{j}}+\Psi_{\mathrm{ij}}
$$

(Equation 1)

where $Y_{i j}$ is the observed mean of genotype $i$ in environment $j ; \beta_{0 i}$ is the linear coefficient related to $\mathrm{i}^{\text {th }}$ genotype; $\beta_{\mathrm{li}}$ is the regression coefficient of genotype $\mathrm{i} ; \mathrm{l}_{\mathrm{j}}$ is the environmental index $\mathrm{j}$; and $\Psi_{\text {ij }}$ represents the random errors that are compounded by the regression deviation of genotype $\mathrm{i}$ in environment $\mathrm{j}$ and by the mean error associated with the mean. The environmental index was estimated using the following equation:

$$
I_{j}=\bar{Y}_{j}-\bar{Y}_{m} \text {, with } \sum_{j=1}^{n} I_{j}=0
$$

where $\bar{Y}_{m}$ is the overall mean; $\bar{Y}_{j}$ is the mean of environment $\mathrm{j}$; and $\mathrm{n}$ is the number of environments. According to the Eberhart and Russell (1966) method, genotype adaptability was measured using the parameter $\beta_{1 i}$, while the stability of behavior was evaluated using the variance 
of the regression deviations $\left(\sigma^{2}{ }_{d i}\right)$ and the coefficient of determination $\left(R^{2}\right)$, which is an auxiliary measure for stability assessment (Cruz and Regazzi, 2007). The $\mathrm{R}^{2}$ value indicates acceptable predictability when $\sigma^{2}{ }_{\text {di }}$ is significant and $\mathrm{R}^{2}$ is higher than $80 \%$. Using this frequentist approach, the hypotheses of interest are: $H_{0}: \beta_{l i}=1$ versus $H_{1}: \beta_{l i} \neq 1$ and $H_{0}: \sigma^{2}{ }_{d i}=0$ versus $H_{1}: \sigma_{d i}^{2}>0$, which are assessed using $t$ and $\mathrm{F}$ statistics, respectively.

For the Bayesian analysis, we only considered genotypes that were evaluated in either Carvalho et al. (2006) or Valadares et al. (2010), which were used as references for the specification of a priori distributions (Table 2).

Table 2. Estimates and means $\left(\beta_{0 \mathrm{i}}\right)$ associated with adaptability $\left(\beta_{1 \mathrm{i}}\right)$ and stability $\left(\sigma_{\mathrm{di}}^{2}\right)$, which were obtained using the Eberhart and Russell method (1966) as described in Freire Filho et al. (2002), Carvalho et al. (2006), and Valadares et al. (2010).

\begin{tabular}{|c|c|c|c|c|}
\hline Genotype & Reference & $\beta_{0 i}(\mathrm{~kg} / \mathrm{ha})$ & $\beta_{1 \mathrm{i}}$ & $\sigma_{\mathrm{di}}^{2}$ \\
\hline MNC99-537F-1 & Valadares et al. (2010) & 1,198 & 0.486 & $47,972.1$ \\
\hline MNC99-537F-4 & Valadares et al. (2010) & 1,009 & 0.626 & $18,000.7$ \\
\hline MNC99-541-F5 & Valadares et al. (2010) & 1,135 & 1.050 & $101,781.9$ \\
\hline MNC99-541-F8 & Valadares et al. (2010) & 982 & 0.523 & $78,858.2$ \\
\hline IT93K-93-10 & Valadares et al. (2010) & 992 & 0.826 & $35,027.7$ \\
\hline MNC99-519D-1-1-5 & Carvalho et al. (2006) & 1,335 & 1.110 & $64,962.3$ \\
\hline MNC00-544D-10-1-2-2 & Carvalho et al. (2006) & 1,341 & 1.280 & $174,507.1$ \\
\hline MNC00-544D-14-1-2-2 & Carvalho et al. (2006) & 1,269 & 1.000 & $25,059.8$ \\
\hline MNC00-553D-8-1-2-2 & Carvalho et al. (2006) & 1,257 & 1.190 & $89,750.1$ \\
\hline MNC00-553D-8-1-2-3 & Carvalho et al. (2006) & 1,113 & 0.860 & $143,440.1$ \\
\hline MNC00-561G-6 & Carvalho et al. (2006) & 1,307 & 1.140 & $47,269.3$ \\
\hline EV X 63-10E & Carvalho et al. (2006) & 1,456 & 1.170 & $48,760.7$ \\
\hline $\mathrm{EV} \times 91-2 \mathrm{E}-2$ & Carvalho et al. (2006) & 1,387 & 1.220 & $68,953.7$ \\
\hline MNC99-557F-2 & Carvalho et al. (2006) & 1,117 & 0.730 & $81,749.1$ \\
\hline BRS Guariba & Carvalho et al. (2006) & 1,377 & 1.190 & $19,336.7$ \\
\hline Patativa & Carvalho et al. (2006) & 1,311 & 0.970 & $97,943.2$ \\
\hline Vita-7 & Carvalho et al. (2006) & 1,468 & 1.170 & $181,246.8$ \\
\hline
\end{tabular}

With the Bayesian approach, we considered the following statistical model:

$$
\mathrm{Y}_{\mathrm{ij}}=\beta_{0 \mathrm{i}}+\beta_{\mathrm{i}} \mathrm{I}_{\mathrm{j}}+\Psi_{\mathrm{ij}}
$$

(Equation 3)

where each $\mathrm{Y}_{\mathrm{ij}}$ observation was assumed to have the following distribution:

$$
\mathrm{Y}_{\mathrm{ij}} \sim \mathrm{N}\left(\beta_{0_{\mathrm{i}}}+\beta_{\mathrm{li}} \mathrm{I}_{\mathrm{j}}: \sigma_{\mathrm{di}}^{2}\right)
$$

where the likelihood function for each genotype $\mathrm{i}$ is given by:

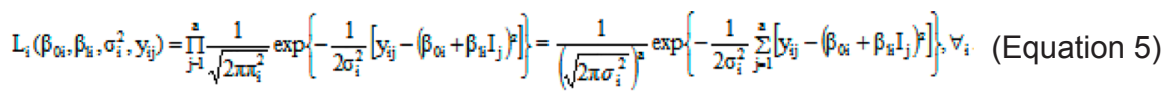

To estimate the adaptability and stability parameters, a priori distributions were assigned for the parameters. The following distributions were considered for $\beta_{0 \mathrm{i}}$, $\beta_{\mathrm{li}}$, and $\sigma_{\mathrm{di}}^{2}$ :

$$
\beta_{0 \mathrm{i}} \sim \mathrm{N}\left(\mu_{0 \mathrm{i}}, \sigma_{0 \mathrm{i}}^{2}\right), \beta_{\mathrm{ir}} \sim \mathrm{N}\left(\mu_{0 \mathrm{i}}, \sigma_{\mathrm{li}}^{2}\right)
$$

(Equation 6) 


\section{$\sigma_{\mathrm{di}}^{2} \sim \operatorname{GamaInv}\left(\alpha_{\mathrm{i}} \cdot \beta_{\mathrm{i}}\right)$.}

(Equation 7)

The equal mean and variance for the reverse gamma values were calculated as follows, respectively:

$$
\begin{gathered}
\frac{\beta_{i}}{\alpha_{i}-1} \\
\frac{\beta_{i}^{2}}{\left(\alpha_{i}-1\right)^{2}\left(\alpha_{i}-2\right)} .
\end{gathered}
$$

When we assumed independence between the parameters of these distributions, the joint a priori distributions for each genotype were given by:

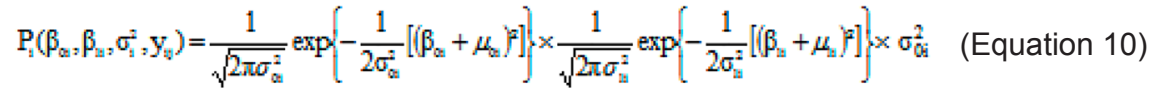

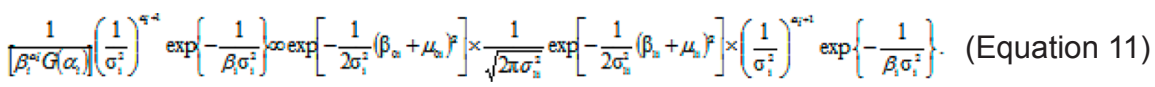

To make inferences about the parameter of interest, the marginal a posteriori distributions must be obtained. When we denoted the parameter vectors for each genotype i using the following equation:

$$
\theta_{\mathrm{pi}}=\left(\beta_{1 \mathrm{i}}, \beta_{2 \mathrm{i}}, \sigma_{3 \mathrm{i}}^{2}\right)
$$

where $p=1,2,3$, the marginal a posteriori distribution for the parameter $\theta_{p i}$ was obtained using the following integral:

$$
\mathrm{P}\left(\theta_{\mathrm{pi}} \mid \mathrm{x}\right)=\int \mathrm{P}\left(\theta_{\mathrm{pi}} \mid \mathrm{x}\right) \mathrm{d} \theta_{\mathrm{pi}}
$$

(i.e., the integral in relation to all vector parameters with the exception of the $\mathrm{p}^{\text {th }}$ component).

In most cases, these integrals were complex and did not have exact solutions. To work around this problem, we used other methodologies. For example, we obtained a sample of the joint a posteriori distribution using the Markov chain and Monte Carlo (MCMC) method, which was used to determine the moments associated with the marginal distributions of interest (Cassela and George, 1992). In this study, the methodology was implemented using the R software (R Development Core Team, 2015), and the joint distribution sample was obtained using the MCMC regression function of the MCMC package.

To evaluate the influence of a priori information when estimating the adaptability and sta- 
bility parameters, we utilized two different models: informative a priori distributions and minimally informative a priori distributions. In Model 1, the informative a priori information was derived from the application of meta-analysis techniques, which were characterized using information from Carvalho et al. (2006) and Valadares et al. (2010).

The 17 genotypes evaluated in the trials were used as references for a priori specification. Therefore, all of the genotypes presented in Table 2 were considered for Bayesian analysis. Information was inserted into the analysis using the assumed values for a priori distribution parameters (i.e., hyperparameters). These values were based on the mean and variance values of the samples that were composed using the parameter estimates obtained from the cited references (Table 2), which resulted in the following distributions:

$$
\begin{gathered}
\beta_{0 \mathrm{i}}-\mathrm{N}\left(\mu_{0 \mathrm{i}}=\bar{\beta}_{0 \mathrm{i},}, \sigma_{1 \mathrm{i}}^{2}=\operatorname{Var}\left(\bar{\beta}_{0 \mathrm{i}}\right)\right) \\
\beta_{\mathrm{ii}} \sim \mathrm{N}\left(\mu_{1 \mathrm{i}}=\bar{\beta}_{1 \mathrm{i},} \sigma_{1 \mathrm{i}}^{2}=\operatorname{Var}\left(\bar{\beta}_{0 \mathrm{i},}\right)\right) \\
\sigma_{\mathrm{di}}^{2} \sim \operatorname{GamaInv}\left(\alpha_{\mathrm{i},}, \beta_{\mathrm{i}}\right)
\end{gathered}
$$

where $\bar{\beta}_{0 i}$ represents the means of the $\beta_{0 i}$ estimates; $\bar{\beta}_{1 i}$ represents the means of the $\beta_{1 i}$ estimates; $\operatorname{Var}\left(\bar{\beta}_{0 i}\right)$ is the variance of the mean $\bar{\beta}_{i n}$ values; $\operatorname{Var}\left(\bar{\beta}_{1 \mathrm{i}}\right)$ is the variance of the mean $\bar{\beta}_{1 \mathrm{i}}$ values; and $\alpha$ and $\beta_{\mathrm{i}}$ represent values obtained using the following system resolution equations:

$$
\begin{gathered}
\bar{\sigma}_{\mathrm{i}}^{2}=\frac{\beta_{\mathrm{i}}}{\alpha_{\mathrm{i}}-1} \\
\operatorname{Var}\left(\bar{\sigma}_{\mathrm{i}}^{2}\right)=\frac{\beta_{\mathrm{i}}^{2}}{\left(\alpha_{\mathrm{i}}-1\right)^{2}\left(\alpha_{\mathrm{i}}-2\right)} \\
\alpha_{\mathrm{i}}=\frac{\left(\sigma_{\mathrm{i}}^{2}\right)^{3}}{\operatorname{Var}\left(\bar{\sigma}_{\mathrm{i}}^{2}\right) \times \bar{\sigma}_{\mathrm{i}}^{2}} \beta_{\mathrm{i}}=\frac{\left(\sigma_{\mathrm{i}}^{2}\right)^{3}}{\operatorname{Var}\left(\bar{\sigma}_{\mathrm{i}}^{2}\right)+\bar{\sigma}_{\mathrm{i}}^{2}}
\end{gathered}
$$

In Model 2, minimally informative a priori distributions were used, and these distributions represented probability distributions with large variance. The following distributions were adopted:

$$
\begin{aligned}
& \beta_{0 \mathrm{i}}-\mathrm{N}\left(\mu_{0 \mathrm{i}}=\beta_{0 \mathrm{i} .} \sigma_{0 \mathrm{i}}^{2}=1,000,000\right) \\
& \beta_{1 \mathrm{i}}-\mathrm{N}\left(\mu_{0 \mathrm{i}}=\beta_{0 \mathrm{i}}, \sigma_{1 \mathrm{i}}^{2}=100,000\right)
\end{aligned}
$$

(Equation 21) 


$$
\beta_{1 i}-\mathrm{N}\left(\mu_{0 \mathrm{i}}=\beta_{0 \mathrm{i}}, \sigma_{1 \mathrm{i}}^{2}=100,000\right)
$$

(Equation 22)

The comparisons between Models 1 and 2 (i.e., between informative and minimally informative a priori distributions) were performed using the Bayes factor calculation (Kass and Raftery, 1995), which was conducted using the BayesFactor function of the MCMC package. According to Jeffreys (1961), Bayes factors can be interpreted as follows: FBij < 1 provides evidence in favor of model $\mathrm{j} ; 1 \leq \mathrm{FBij}<3$ provides moderate evidence in favor of model $\mathrm{i} ; 3 \leq \mathrm{FBij}<10$ indicates substantial evidence in favor of model $\mathrm{i} ; 10 \leq \mathrm{FBij}<30$ demonstrates strong evidence in favor of model $\mathrm{i} ; 30 \leq \mathrm{FBij}<100$ provides very strong evidence in favor of model $\mathrm{i}$; and $\mathrm{FBij} \geq 100$ indicates decisive evidence in favor of model $\mathrm{i}$.

Regarding the stability parameter $\left(\sigma^{2}{ }_{\text {di }}\right)$, samples of its marginal distributions were obtained indirectly, because this parameter represents a function. When values for $\sigma^{2}{ }_{i}$ were obtained indirectly in each iteration, we acquired values for $\sigma^{2}{ }_{\mathrm{di}}$ using the following expression:

$$
\hat{\sigma}_{d i}^{2}=\hat{\sigma}_{i}^{2}-(\mathrm{MSR} / \mathrm{r})
$$

(Equation 23)

where MSR is the mean square of the residue provided by ANOVA; and $r$ is the number of repetitions in the trial.

The hypotheses of interest were tested by constructing credibility ranges for the parameters, and the intervals were obtained directly from the marginal a posteriori distribution of the parameters. Thus, the credibility interval $(\mathrm{Cl})$ for $\theta_{\mathrm{i}}$, with a probability of covering $\delta$, is given by:

$$
\begin{aligned}
& \int_{-\infty}^{\theta_{*}} \mathrm{P}_{\mathrm{i}}\left(\theta_{\mathrm{i}}=\left(\beta_{0 \mathrm{i}} \beta_{\mathrm{li}}: \sigma_{\mathrm{di}}^{2}\right) \mid \mathrm{y}_{\mathrm{ij}}\right) \mathrm{d} \theta_{\mathrm{i}}=\alpha / 2 \\
& \int_{\theta^{*}}^{-\infty} \mathrm{P}_{\mathrm{i}}\left(\theta_{\mathrm{i}}=\left(\beta_{0 \mathrm{i}} \beta_{\mathrm{li}}: \sigma_{\mathrm{di}}^{2}\right) \mid \mathrm{y}_{\mathrm{ij}}\right) \mathrm{d} \theta_{\mathrm{i}}=\alpha / 2
\end{aligned}
$$

where $\theta_{*}$ and $\theta^{*}$ represent the lower and upper limits of the $\mathrm{Cl}$, respectively. Since the Gibbs sampler is an iterative algorithm, it is necessary to check its convergence. In this study, the convergence was checked by applying the Heidelberger and Welch (1983), Raftery and Lewis (1992), and Geweke (1992) criteria, which were implemented in the Bayesian Output Analysis package of the R program (R Development Core Team, 2015).

Regarding Bayesian analyses of adaptability and stability for each parameter of the adopted regression model, 110,000 iterations in the Gibbs sampler algorithm with a warm period ("burn-in") of 10,000 iterations were considered. To obtain a non-correlated sample, we considered the spacing between the sampling points of two iterations ("thinning"), which resulted in a final sample size of 50,000 . The samples represented samples of marginal a posteriori distributions for each parameter under which the inference was conducted. 


\section{RESULTS AND DISCUSSION}

In joint analyses, all of the effects were significant $(P \leq 0.01)$ (Table 3$)$, which indicated contrasts between the environments and the occurrence of genotypic differential responses to environmental effects. This can be confirmed by examining differences in the soil and climatic features of each environment, including altitude, latitude, longitude, climate type, soil type, rainfall, and temperature (Table 1). Similar results were obtained in previous studies that found significant differences associated with the effects of genotypes, environments, and $G \times E$ interactions when evaluating cowpea genotypes in multi-environment trials in the Brazilian Cerrado (Rocha et al., 2007; Barros et al., 2013; Santos et al., 2015; Torres et al., 2015b). The existence of significant G x $E$ interactions for YIE that the stability and adaptability analyses were suitable, and this result was further supported by the fact that edaphoclimatic factors had the greatest influence on the adaptability and stability of genotypes.

Table 3. Summary of joint ANOVA for grain yield (kg/ha) of 17 upright cowpea genotypes that were evaluated in six environments in the State of Estado do Mato Grosso do Sul.

\begin{tabular}{l|c|c}
\hline Sources of variation & d.f. & Mean square \\
\hline Blocks/Environment & 18 & $230,431.83$ \\
\hline Genotypes & 16 & $237,309.26^{*}$ \\
\hline Environment & 5 & $10,921,770.95^{*}$ \\
\hline Genotypes x Environment & 57 & $189,533.11^{*}$ \\
\hline Error & 190 & $47,623.88$ \\
\hline Mean (kg/ha) & - & 664.43 \\
\hline Coefficient of variation (\%) & - & 25.32 \\
\hline
\end{tabular}

*Significant at a 0.01 probability level using the $F$ test.

Regarding the convergence for all simulated chains, the dependency factor of Raftery and Lewis (1992) gave values lower than five, and $P$ values based on the criteria of Geweke (1992) were higher than the prefixed significance level $(P \leq 0.05)$ (i.e., both criteria indicated convergence of the chains generated by the Gibbs sampler). In order to confirm this convergence, we also used the criteria of Heidelberger and Welch (1983), which determined whether the chain values were derived from a stationary distribution.

The adaptability and stability parameter estimated values were obtained by calculating the a posteriori means, which are presented together with their respective Cls in Table 4. In Model 1 (informative a priori), of the 17 genotypes evaluated by the Bayesian approach, only the EV X 63-10E, BRS Guariba, and Vita-7 genotypes were classified as having specific adaptability to favorable environments $\left(\beta_{1 i}>1\right)(\mathrm{Cl}$ limits at $95 \%)$. The other genotypes were classified as having general adaptability and stability, since the value of 1 fell within a $\mathrm{Cl}$ of $95 \%$. However, when considering the analysis of genotypes under Model 2 conditions (minimally informative a priori), all genotypes showed specific adaptability to favorable environments $\left(\beta_{1 i}>1\right)$. Therefore, it is possible to infer that the use of the frequentist model, in which a priori information is not taken into account, tends to conclude that the genotypes exhibit stability and adaptability to different environments, but this does not favor reliable genotype recommendations. Nascimento et al. (2011) and Couto et al. (2015) obtained similar results after evaluating the adaptability and phenotypic stability of alfalfa and popcorn genotypes, respectively. 
Table 4. Estimates of a posteriori mean $\left(\bar{\beta}_{0 i}\right.$, in $\left.\mathrm{kg} / \mathrm{ha}\right)$ and credibility intervals $(95 \%)$ of the adaptability $\left(\bar{\beta}_{1 \mathrm{i}}\right)$ and stability $\left(\bar{\sigma}_{i}^{2}\right)$ parameters when considering informative and minimally informative a priori distributions.

\begin{tabular}{|c|c|c|c|c|c|c|c|c|c|c|}
\hline Genotype & LI $\bar{\beta}_{0 i}$ & $\bar{\beta}_{0 i}$ & $\operatorname{LS} \bar{\beta}_{0 i}$ & 니 $\bar{\beta}_{l i}$ & $\bar{\beta}_{l i}$ & LS $\bar{\beta}_{l i}$ & $\begin{array}{c}\bar{\sigma}_{i}^{2} \\
\times 1000 \\
\end{array}$ & $\begin{array}{l}\mathrm{LI} \bar{\sigma}_{\mathrm{di}}^{2} \\
\mathrm{x} 1000 \\
\end{array}$ & $\begin{array}{r}\bar{\sigma}_{\mathrm{di}}^{2} \\
\times 1000 \\
\end{array}$ & $\begin{array}{l}\text { LS } \bar{\sigma}_{\mathrm{di}}^{2} \\
\mathrm{x} 1000\end{array}$ \\
\hline \multicolumn{11}{|l|}{ Informative a priori } \\
\hline MNC99-537F-1 & 649 & 962 & 1331 & 0.12 & 0.60 & 1.01 & 344.5 & 2.7 & 336.6 & 1738.1 \\
\hline MNC99-537F-4 & 740 & 837 & 1013 & 0.60 & 1.03 & 1.24 & 26.2 & -6.9 & 18.3 & 159.6 \\
\hline MNC99-541-F5 & 662 & 825 & 1154 & 0.73 & 1.07 & 1.40 & 81.7 & -4.6 & 73.7 & 479.6 \\
\hline MNC99-541-F8 & 544 & 788 & 1114 & 0.22 & 0.75 & 1.20 & 254.3 & 1.9 & 246.4 & 1280.1 \\
\hline IT93K-93-10 & 509 & 764 & 1105 & 0.36 & 0.76 & 1.19 & 235.7 & 6.6 & 227.8 & 1181.1 \\
\hline MNC99-519D-1-1-5 & 784 & 1159 & 1509 & 0.62 & 1.08 & 1.55 & 721.8 & 36.9 & 713.9 & 3348.1 \\
\hline MNC00-544D-10-1-2-2 & 581 & 873 & 1382 & 0.64 & 1.10 & 1.43 & 305.1 & -7.6 & 297.2 & 1823.1 \\
\hline MNC00-544D-14-1-2-2 & 654 & 944 & 1451 & 0.88 & 1.24 & 1.66 & 293.6 & -7.5 & 285.7 & 1772.1 \\
\hline MNC00-553D-8-1-2-2 & 753 & 1101 & 1440 & 0.69 & 1.16 & 1.63 & 800.6 & 63.0 & 792.7 & 3659.1 \\
\hline MNC00-553D-8-1-2-3 & 586 & 722 & 1108 & 0.63 & 1.01 & 1.26 & 71.8 & -6.9 & 63.9 & 508.9 \\
\hline MNC00-561G-6 & 735 & 1090 & 1457 & 0.70 & 1.15 & 1.59 & 469.3 & 11.6 & 461.4 & 2288.1 \\
\hline $\mathrm{EV} \times 63-10 \mathrm{E}$ & 966 & 1311 & 1646 & 1.13 & 1.31 & 1.46 & 928.0 & 83.9 & 920.1 & 4187.1 \\
\hline EV X 91-2E-2 & 687 & 972 & 1498 & 0.84 & 1.23 & 1.61 & 297.7 & -7.7 & 289.8 & 1831.1 \\
\hline MNC99-557F-2 & 539 & 721 & 1165 & 0.45 & 0.89 & 1.16 & 129.9 & -7.1 & 121.9 & 869.6 \\
\hline BRS Guariba & 819 & 1192 & 1545 & 1.03 & 1.15 & 1.26 & 651.2 & 29.3 & 643.3 & 3039.1 \\
\hline Patativa & 620 & 945 & 1432 & 0.56 & 0.96 & 1.37 & 337.2 & -7.4 & 329.3 & 1926.1 \\
\hline Vita-7 & 1036 & 1364 & 1687 & 1.27 & 1.35 & 1.43 & 1775.0 & 232.9 & 1767.1 & 7738.1 \\
\hline \multicolumn{11}{|c|}{ Minimally informative a priori } \\
\hline MNC99-537F-1 & 318 & 633 & 939 & 0.14 & 0.87 & 1.60 & 238.8 & -2.3 & 230.9 & 785.8 \\
\hline MNC99-537F-4 & 640 & 811 & 977 & 0.74 & 1.14 & 1.53 & 76.0 & -6.3 & 68.1 & 229.9 \\
\hline MNC99-541-F5 & 450 & 705 & 952 & 0.50 & 1.09 & 1.68 & 160.4 & -4.2 & 152.5 & 517.1 \\
\hline MNC99-541-F8 & 262 & 568 & 867 & 0.50 & 1.21 & 1.92 & 227.5 & -2.5 & 219.6 & 747.8 \\
\hline IT93K-93-10 & 74 & 513 & 940 & -0.41 & 0.61 & 1.63 & 448.5 & 3.3 & 440.6 & 1534.1 \\
\hline MNC99-519D-1-1-5 & 245 & 612 & 969 & 0.03 & 0.88 & 1.73 & 319.4 & -0.1 & 311.5 & 1070.1 \\
\hline MNC00-544D-10-1-2-2 & 472 & 598 & 721 & 0.91 & 1.20 & 1.49 & 42.9 & -7.0 & 35.1 & 122.7 \\
\hline MNC00-544D-14-1-2-2 & 542 & 671 & 799 & 0.91 & 1.21 & 1.51 & 45.6 & -6.9 & 37.6 & 130.9 \\
\hline MNC00-553D-8-1-2-2 & 216 & 5289 & 1040 & -0.29 & 0.94 & 2.16 & 634.0 & 8.4 & 626.1 & 2198.1 \\
\hline MNC00-553D-8-1-2-3 & 458 & 622 & 783 & 0.70 & 1.08 & 1.45 & 70.3 & -6.4 & 62.4 & 212.2 \\
\hline MNC00-561G-6 & 291 & 667 & 1032 & 0.30 & 1.17 & 2.04 & 333.8 & 0.2 & 325.9 & 1119.1 \\
\hline EV X 63-10E & 124 & 684 & 1220 & -0.34 & 0.95 & 2.25 & 710.0 & 10.4 & 702.1 & 2466.1 \\
\hline $\mathrm{EV} \times 91-2 \mathrm{E}-2$ & 579 & 703 & 824 & 0.95 & 1.24 & 1.52 & 41.7 & -7.1 & 33.8 & 118.4 \\
\hline MNC99-557F-2 & 411 & 567 & 721 & 0.61 & 0.98 & 1.34 & 64.9 & -6.5 & 56.9 & 194.7 \\
\hline BRS Guariba & 292 & 677 & 1050 & 0.12 & 1.01 & 1.90 & 348.8 & 0.6 & 340.9 & 1172.1 \\
\hline Patativa & 501 & 635 & 767 & 0.63 & 0.94 & 1.25 & 48.5 & -6.9 & 40.6 & 140.4 \\
\hline Vita-7 & 111 & 473 & 924 & -0.41 & 0.67 & 1.74 & 495.7 & 4.6 & 487.8 & 1706.1 \\
\hline
\end{tabular}

By comparing the estimates of the parameters obtained using the two models, similar differences in magnitude between the parameters were observed. Thus, it is necessary to determine which of the two models exhibited a higher quality setting, and this answer was provided using Bayes factor calculations (Nascimento et al., 2011). With the exception of the MNC99-519D-1-1-5, MNC00-544D-10-1-2-2, MNC00-553D-8-1-2-2, MNC00-561G-6, EV X 91-2E-2, Patativa, and Vita7 genotypes, all of the other genotypes exhibited Bayes factors that were greater than 10 (Table 5).

These results indicated that the use of informative a priori distributions provided more accurate results. Despite the a priori information for each genotype that was based on a single study, similar results were found in studies that evaluated the adaptability and phenotypic stability of the dry matter yield of alfalfa genotypes (Nascimento et al., 2011), popcorn grain yield (Couto et al., 2015) and cowpea YIE (Teodoro et al., 2015). Therefore, it is expected that the results will be more accurate in studies examining the stability and adaptability of other crops that have larger amounts of available information for meta-analysis.

The Bayesian approach, in conjunction with the Eberhart and Russell method (1966), was an effective method for the selection of upright cowpea genotypes with high adaptability and phenotypic stability. Moreover, Bayes factors indicated that the use of informative a priori distributions provided more accurate results compared to minimally a priori distributions. 
Table 5. Values obtained for Bayes factors (BF) of models compared using informative a priori (i) and minimally informative a priori (j) distributions for the evaluated genotypes.

\begin{tabular}{l|c}
\hline Genotype & $\mathrm{BF}_{\mathrm{ij}}$ \\
\hline MNC99-537F-1 & 11.20 \\
\hline MNC99-537F-4 & 14.90 \\
\hline MNC99-541-F5 & 13.80 \\
\hline MNC99-541-F8 & 11.80 \\
\hline IT93K-93-10 & 13.70 \\
\hline MNC99-519D-1-1-5 & 8.12 \\
\hline MNC00-544D-10-1-2-2 & 9.12 \\
\hline MNC00-544D-14-1-2-2 & 9.29 \\
\hline MNC00-553D-8-1-2-2 & 8.33 \\
\hline MNC00-553D-8-1-2-3 & 12.60 \\
\hline EV X 63-10E & 9.73 \\
\hline EV X 91-2E-2 & 10.80 \\
\hline MNC99-557F-2 & 9.21 \\
\hline BRS Guariba & 11.30 \\
\hline Patativa & 11.90 \\
\hline Vita-7 & 9.02 \\
\hline MNC99-537F-1 & 2.29 \\
\hline MNC99-537F-4 & 11.20 \\
\hline MNC99-541-F5 & 14.90 \\
\hline
\end{tabular}

\section{Conflicts of interest}

The authors declare no conflict of interest.

\section{ACKNOWLEDGMENTS}

Research supported by Coordenação de Aperfeiçoamento de Pessoal de Nível Superior (CAPES) and Conselho Nacional de Desenvolvimento Científico e Tecnológico (CNPq).

\section{REFERENCES}

Banzatto DA and Kronka SN (2006). Experimentação agrícola. FUNEP, Jaboticabal.

Barros MA, Rocha MM, Gomes RLF, Silva KJD, et al. (2013). Adaptabilidade e estabilidade produtiva de feijão-caupi de porte semiprostrado. Pesq. Agropec. Bras. 48: 403-410. http://dx.doi.org/10.1590/S0100-204X2013000400008

Carvalho HWL, Brito Neto J, Freire Filho FR, Rocha MM, et al. (2006). Estabilidade de linhagens de feijão-caupi de porte ereto. In: Anais do Congresso Nacional de Feijão-caupi, Teresina.

Cassela G and George El (1992). Explaining the Gibbs sampler. Am. Stat. 46: 167-174.

Cotes JM, Crossa A, Sanches PL and Cornelius A (2006). Bayesian approach for assessing the stability of genotypes. Crop Sci. 46: 2654-2665. http://dx.doi.org/10.2135/cropsci2006.04.0227

Couto MF, Nascimento M, Amaral AT, Silva FF, et al. (2015). Eberhart and Russel's bayesian method in the selection of popcorn cultivars. Crop Sci. 55: 571-577. http://dx.doi.org/10.2135/cropsci2014.07.0498

Cruz CD and Regazzi AJ (2007). Modelos biométricos aplicados ao melhoramento genético. Imprensa Universitária, Viçosa.

Eberhart SA and Russell WA (1966). Stability parameters for comparing varieties. Crop Sci. 6: 36-40. http://dx.doi.org/10.2135/ cropsci1966.0011183X000600010011x

Freire Filho FR, Ribeiro VQ, Rocha MM and Lopes ACA (2002). Adaptabilidade e estabilidade da produtividade de grãos de linhagens de caupi de porte enramador. Rev. Ceres 49: 383-393.

Geweke J (1992). Evaluating the accuracy of sampling-based approaches to the calculation of posterior moments. In: Bayesian statistics (Bernardo JM, Berger JO, David AP and Smith AFM eds.). Oxford University, New York.

Heidelberger $P$ and Welch PD (1983). Simulation run length control in the presence of an initial transient. Oper. Res. 31: 11091144. http://dx.doi.org/10.1287/opre.31.6.1109 
Jeffreys $\mathrm{H}$ (1961). Theory of probability. Claredon, Oxford.

Kass RE and Raftery AE (1995). Bayes factors. J. Am. Stat. Assoc. 90: 773-795. http://dx.doi.org/10.1080/01621459.1995.1 $\underline{0476572}$

Molina LMR, Sanches A and Torres JMC (2011). Inferência bayesiana na análise de testes regionais de arroz em dois sistemas de cultivo. Rev. Fac. Nac. Agro. 64: 5883-5891.

Mora F, Scapim CA and Pinto RJB (2009). El análisis bayesiano y la precisión de los valores de la heredabilidad en especies perenes. Cienc. Florest. 19: 343-349. http://dx.doi.org/10.5902/19805098890

Nascimento M, Silva FF, Sáfadi T, Nascimento ACC, et al. (2011). Abordagem bayesiana para avaliação da adaptabilidade e estabilidade de genotipos de alfafa. Pesq. Agropec. Bras. 46: 26-32. http://dx.doi.org/10.1590/S0100-204X2011000100004

R Development Core Team R: a language and environment for statistical computing. Vienna: R Foundation for Statistical Computing. http://www.R- project.org. Accessed April 15, 2015.

Raftery AL and Lewis SM (1992). Practical markov chain monte carlo: comment: one long run with diagnostics: implementation strategies for Markov chain Monte Carlo. Stat. Sci. 7: 493-497. http://dx.doi.org/10.1214/ss/1177011143

Rocha MM, Freire Filho FR, Ribeiro VQ, Carvalho HWL, et al. (2007). Adaptabilidade e estabilidade produtiva de genótipos de feijão-caupi de porte semiereto na região Nordeste do Brasil. Pesq. Agropec. Bras. 42: 1283-1289. http://dx.doi. org/10.1590/S0100-204X2007000900010

Santos A, Ceccon G, Rodrigues EV, Teodoro PE, et al. (2015). Adaptability and stability of cowpea genotypes to Brazilian Midwest. Afr. J. Agric. Res. 10: 3901-3908.

Santos JAS, Teodoro PE, Correa AM, Soares CMG, et al. (2014a). Desempenho agronômico e divergência genética entre genótipos de feijão-caupi cultivados no ecótono Cerrado/Pantanal. Bragantia 73: 377-382. http://dx.doi.org/10.1590/1678$\underline{4499.0250}$

Santos JAS, Soares CMG, Corrêa AM, Teodoro PE, et al. (2014b). Agronomic performance and genetic dissimilarity among cowpea [Vigna unguiculata (L.) Walp.] genotypes. Glob. Adv. Res. J. Agr. Sci. 3: 271-277.

Silva MAG, Peternelli LA, Nascimento M and Silva FL (2013). Modelos mistos na seleção de famílias de cana de açúcar aparentados sob o enfoque clássico e bayesiano. Rev. Bras. Biol. 31: 1-12.

Teodoro PE, Nascimento M, Torres FE, Barroso LMA, et al. (2015). Perspectiva baysiana na seleção de genótipos de feijão-caupi em ensaios de valor de cultivo e uso. Pesq. Agropec. Bras. 50: 878-885. http://dx.doi.org/10.1590/S0100$\underline{204 X 2015001000003}$

Torres FE, Sagrilo E, Teodoro PE, Ribeiro LP, et al. (2015a). Número de repetições para avaliação de caracteres em genótipos de feijão-caupi. Bragantia 74: 161-168. http://dx.doi.org/10.1590/1678-4499.0393

Torres FE, Teodoro PE, Sagrilo E, Correa AM, et al. (2015b). Interação genótipo x ambiente em genótipos de feijão-caupi semiprostrado via modelos mistos. Bragantia 74: 255-260. http://dx.doi.org/10.1590/1678-4499.0099

Valadares RN, Moura MCCL, Silva AFA, Silva LS, et al. (2010). Adaptabilidade e estabilidade fenotípica em genótipos de feijão-caupi [Vigna unguiculata (L.) Walp.] de porte ereto/semiereto nas mesorregiões leste e sul maranhense. Agropec. Cien. Semi-Árido 6: 21-27.

Wricke G (1965). Zur berechnung der okovalenz bei sommerweizen und hafer. Z. Pflanzenzuchtg 52: 127-138.

Yates F and Cochran WG (1938). The analysis of group of experiments. J. Agric. Sci. 28: 556-580. http://dx.doi.org/10.1017/ $\underline{\mathrm{S} 0021859600050978}$ 